УДК 636.2.034.082

doi: $10.36359 /$ scivp.2019-20-2.48

\title{
ДИНАМІКА ВАГОВОГО РОСТУ ТЕЛИЦЬ СИМЕНТАЛЬСЬКОЇ ПОРОДИ РІЗНИХ ВИРОБНИЧИХ ТИПІВ
}

\author{
T. В. Оріхівський, асистент ${ }^{1}$ \\ B. В. Федорович, д-р с.-г. наук, с. н. с. ${ }^{2,3}$ \\ Н. П. Мазур, д-р с.-г. наук ${ }^{4}$ \\ А. Пирлог, канд. с.-г. наук, доцент ${ }^{5}$
}

${ }^{1}$ Львівський національний університет ветеринарної медицини та біотехнологій імені С. 3. Гжицького, вул. Пекарська, 50, м. Львів, 79000, Україна

${ }^{2}$ Інститут розведення і генетики тварин імені М. В. Зубця НААН, вул. Погребняка, 1, с. Чубинське Бориспільського району Київської області, 08321, Україна

${ }^{3}$ Інститут сільського господарства Карпатського регіону НААН, вул. Грушевського, 5, с. Оброшино, Пустомитівського району Львівської області, 81115, Україна

${ }^{4}$ Інститут біології тварин НААН,

вул. В. Стуса, 38, м. Львів, 79034, Україна

5 Державний аграрний університет Молдови, вул. Мірчєшть, 42, м. Кишинів, MD 2049, Молдова

Наведено дані вагового росту корів симентальської породи у період вирощування у молодому вічі залежно від їх виробничого типу. Встановлено, що тварини за живою масою у 6-місячному віці переважали стандарт породи на 20,2, у 12-місячному - на 39,1 та у 18місячному - на 51,6 кг. Вік першого осіменіння телиць у підконтрольному стаді становив 18,0, а вік першого отелення - 27,2 місячя при живій масі 433,7 та 529,1 кг відповідно. У всі досліджувані періоди росту найнижчими показниками живої маси, кратності збільшення живої маси та середньодобових приростів характеризувалися тварини молочного типу, а найвищими - м'ясо-молочного. Телиці м'ясо-молочного типу відзначалися кращою скороспілістю. Вік першого осіменіння у них становив 17,5 місяия, тоді як у особин молочном'ясного типу - 18,4, а м'ясо-молочного типу - 18,0 місяців. Сила впливу належності тварин до виробничого типу на формування їх живої маси, залежно від періоду вирощування, становила 8,8-36,9\% від загальної фенотипової мінливості, причому найменше даний фактор впливав на живу масу новонародженого молодняку (8,8\%) та на живу масу тварин після першого отелення (13,4\%).

Ключові слова: СИМЕНТАЛЬСЬКА ПОРОДА, ВИРОБНИЧИЙ ТИП, ТЕЛИЦІ, ЖИВА МАСА, СЕРЕДНЬОДОБОВІ ПРИРОСТИ, ВІК ПЕРШОГО ОСІМЕНІННЯ, ВІК ПЕРШОГО ОТЕЛЕННЯ, СИЛА ВПЛИВУ.

Одним із важливих факторів економічної ефективності галузі молочного скотарства $€$ вирощування ремонтних телиць. Прискорення темпів оновлення молочних стад потребує істотної перебудови організації і техніки вирощування ремонтного молодняку, що повинно базуватись на закономірностях їх індивідуального розвитку і сприяти формуванню тварин із міцною конституцією та високою продуктивністю [8]. Дослідженнями багатьох вчених встановлена залежність майбутньої молочної продуктивності корів від їх живої маси у період вирощування. Зокрема, Т. П. Коваль [6], М. Базишин [2] повідомляють, що найінтенсивніший 
розвиток тварин відбувається у ранньому віці. Його затримка в перші місяці життя не компенсується повністю у старшому віці. Тому, важливо знати потенційні можливості організму кожної тварини, починаючи з її народження, оскільки генетично запрограмована продуктивність корів може бути реалізована лише за сприятливого їх вирощування у різні вікові періоди в молодому віці. М. Гавриленко [5] застерігає, що низький і дуже високий рівень годівлі при вирощуванні молочних корів можуть як сприяти формуванню високої молочної продуктивності, так і пригнічувати іiі. Тому, на його думку, для ремонтних телиць оптимальним $\epsilon$ рівень вирощування, коли телиці мають середньодобовий приріст $750-800$ г. Інші дослідники [4] вважають, що молодняк, який впродовж усього періоду вирощування (від народження до 18 місяців) має середньодобовий приріст вищий 750 г, схиляється в бік м'ясомолочного типу продуктивності та характеризується нижчою майбутньою молочною продуктивністю порівняно з тваринами, у яких середньодобовий приріст є на рівні 600 г. В. В. Федорович [9] встановив, що найвищі надої та кількість молочного жиру у корів симентальської породи спостерігалися за їх живої маси при народженні 33-34 кг, у 6місячному віці - 171-190, у 12-місячному - 291-300, у 18-місячному - 401-415, при першому осіменінні - 416-430 та при першому отеленні - 501-530 кг.

Сучасні стада симентальської худоби представлені тваринами кількох виробничих типів: молочного, молочно-м'ясного, м'ясо-молочного та м'ясного. Худоба цих типів відрізняється між собою за розвитком живої маси та екстер'єром, а відповідно - і за молочною та м'ясною продуктивністю [3, 10]. 3 огляду на зазначене, метою наших досліджень було вивчити динаміку живої маси корів симентальської породи різних виробничих типів у період їх вирощування.

Матеріали і методи. Дослідження проведені у СГТзОВ «Літинське» Дрогобицького району Львівської області на коровах симентальської породи. До вибірки залучено 161 повновікову корову із закінченою третьою лактацією. Розподіл корів на виробничі типи проводили за методикою, описаною 3. Айсановым [1].

Живу масу корів у період їх вирощування визначали у віці 6, 12, 18 місяців, при першому осіменінні та після першого отелення за даними первинного зоотехнічного обліку. На основі цих показників вираховували середньодобові прирости тварин у різні вікові періоди, кратність збільшення, відносну швидкість та напругу росту живої маси.

Середньодобовий приріст за окремі періоди і за весь період вирощування (0-18 міс.) тварин визначали за формулою:

$$
\mathrm{R}=\frac{W t-W o}{t_{2}-t_{1}}
$$

де: $\mathrm{W}_{\mathrm{t}} \mathrm{i} \mathrm{W}_{\mathrm{o}}$ - кінцева та початкова жива маса, кг;

$\mathrm{t}_{2} \mathrm{i}_{1}-$ вік у кінці та на початку періоду, дні.

Відносну швидкість росту (К) вираховували за формулою С. Броді:

$$
\mathrm{K}=\frac{W t-W o}{0,5 \cdot(W t+W o)} \times 100,
$$

Кратність збільшення живої маси визначали шляхом ділення живої маси 6-, 12- і 18місячному віці на живу масу новонароджених тварин.

Напругу росту (Н) обчислювали за коефіцієнтами приросту:

$$
H=\frac{W_{t}-W_{o}}{W_{o}} \times 100 .
$$

За допомогою однофакторного дисперсійного аналізу з використанням програмного пакету «STATISTICA-6,1» вивчали силу впливу належності корів до виробничого типу на їх живу масу. 
Отримані результати досліджень обробляли методом варіаційної статистики за Г. Ф. Лакиным [7] 3 використанням комп'ютерної програми “Excel”. Результати середніх значень вважали статистично вірогідними при $\mathrm{P}<0,05$ (*), $\mathrm{P}<0,01$ (**), $\mathrm{P}<0,001$ (***).

Результати й обговорення. Важливою складовою селекційно-племінної роботи 3 породою є об'єктивна оцінка ремонтного молодняку великої рогатої худоби за живою масою на перших етапах постнатального онтогенезу. Нами встановлено, що телички симентальської породи характеризувалися високими показниками живої маси у всі досліджувані вікові періоди (табл. 1). Зокрема, новонароджені телята мали середню живу масу 38,3 кг, а до 18-місячного віку тварин вона збільшилася на 393,3 кг і становила 431,6 кг.

Динаміка росту та кратність збільшення живої маси корів симентальської породи

Таблиия 1 у період їх вирощування, $n=161$

\begin{tabular}{|c|c|c|c|c|c|c|}
\hline \multirow{2}{*}{ Вік тварин } & \multicolumn{3}{|c|}{ Жива маса } & \multicolumn{2}{c|}{ Кратність збільшення живої маси } \\
\cline { 2 - 7 } & $\mathrm{M} \pm \mathrm{m}$, кг & $\sigma$ & $\mathrm{Cv}, \%$ & $\mathrm{M} \pm \mathrm{m}$, рази & $\sigma$ & $\mathrm{Cv}, \%$ \\
\hline Новонароджені & $38,3 \pm 0,12$ & 1,55 & 4,04 & - & - & - \\
\hline 6 міс. & $190,2 \pm 0,69$ & 8,74 & 4,60 & $4,9 \pm 0,16$ & 0,20 & 4,08 \\
\hline 12 міс. & $323,1 \pm 1,16$ & 14,74 & 4,56 & $8,4 \pm 0,04$ & 0,38 & 4,50 \\
\hline 18 міс. & $431,6 \pm 1,30$ & 17,73 & 4,11 & $11,4 \pm 0,04$ & 0,48 & 4,21 \\
\hline При першому осіменінні & $433,7 \pm 1,96$ & 24,80 & 5,47 & - & - & - \\
\hline При першому отеленні & $529,1 \pm 1,33$ & 16,84 & 3,18 & - & - & - \\
\hline
\end{tabular}

Від народження до 6-місячного віку цей показник збільшився в 4,9, до 12-місячного - в 8,4 і до 18 -місячного - в 11,4 раза.

Слід зазначити, що піддослідний молодняк за живою масою у всі вікові періоди переважав стандарт породи: у 6-місячному віці - на 20,2, у 12-місячному - на 39,1 та у 18місячному - на 51,6 кг.

Вік першого осіменіння телиць симентальської породи у підконтрольному стаді становив у середньому 18,0, а вік першого отелення - 27,2 місяця при живій масі 433,7 та 529,1 кг відповідно. Коефіцієнт мінливості живої маси, залежно від вікового періоду, коливався від 3,18 до 5,47 \%, що свідчить про добру консолідованість молодняку за цією ознакою.

Найвищі середньодобові прирости живої маси телиць відмічені у період від народження до 6-місячного віку (833,8 г), а в подальшому вони поступово знижувалися (табл. 2). За період вирощування від народження до 18-місячного віку тварин зазначений показник становив 729,1 г. Мінливість середньодобових приростів, залежно від вікового періоду, знаходилися в межах 4,00-6,68 \%.

Таблиия 2

Середньодобові прирости живої маси корів у період їх вирощування, n=161

\begin{tabular}{|c|c|c|c|}
\hline \multirow{2}{*}{ Віковий період, місяці } & \multicolumn{3}{|c|}{ Середньодобовий приріст } \\
\cline { 2 - 4 } & $\mathrm{M} \pm \mathrm{m}, \Gamma$ & $\sigma$ & $\mathrm{Cv}, \%$ \\
\hline $0-6$ & $833,8 \pm 3,45$ & 43,83 & 5,26 \\
\hline $6-12$ & $728,4 \pm 3,57$ & 43,33 & 6,22 \\
\hline $12-18$ & $626,1 \pm 3,30$ & 41,87 & 6,68 \\
\hline $0-18$ & $729,1 \pm 2,30$ & 29,17 & 4,00 \\
\hline
\end{tabular}

Вищі показники відносної швидкості та напруги росту живої маси телиць відмічені у період від народження до 6-місячного віку тварин, у подальшому з кожним наступним віковим періодом вони знижувалися (табл. 3). Водночас коефіцієнти мінливості вищенаведених показників у названий віковий період були найнижчими і з віком тварин вони зростали. 
Відносна швидкість та напруга росту живої маси корів у період їх вирощування, n=161

\begin{tabular}{|c|c|c|c|c|c|c|}
\hline \multirow{2}{*}{$\begin{array}{c}\text { Віковий } \\
\text { період, місяці }\end{array}$} & \multicolumn{2}{|c|}{ Відносна швидкість росту } & \multicolumn{3}{c|}{ Коефіціснт приросту } \\
\hline $0-6$ & $132,8 \pm 0,18$ & 2,27 & 1,71 & $396,7 \pm 1,60$ & 20,28 & 5,11 \\
\hline $6-12$ & $51,8 \pm 0,17$ & 2,13 & 4,12 & $69,9 \pm 0,31$ & 3,89 & 5,56 \\
\hline $12-18$ & $30,1 \pm 0,16$ & 2,05 & 6,82 & $35,4 \pm 0,22$ & 2,82 & 7,96 \\
\hline
\end{tabular}

Встановлено, що жива маса ремонтних теличок залежала від їх виробничого типу (табл. 4). У всі досліджувані періоди росту найнижчою живою масою характеризувалися тварини молочного типу, а найвищою - м'ясо-молочного. Телята, які належали до молочного типу народжувалися 3 нижчою живою масою порівняно з ровесниками молочно-м'ясного i м'ясо-молочного типу на 0,3 та 1,7 кг $(\mathrm{P}<0,01)$. У 6 -місячному віці тварин різниця за цим показником між особинами наведених груп становила 4,7 (P<0,01) та $18,0(\mathrm{P}<0,001)$, у 12 місячному - 9,9 ( $\mathrm{P}<0,001)$ та 30,0 ( $\mathrm{P}<0,001)$, у 18-місячному - 13,9 (P<0,0 1) та 38,3 кг $(\mathrm{P}<0,001)$, при першому осіменінні - 8,0 (P<0,01) та 23,2 (P<0,001) і при першому отеленні - 6,2 (P<0,05) та 18,8 кг $(\mathrm{P}<0,001)$. Утім, слід зазначити, що перше осіменіння телиць молочного типу відбувалося у віці 18,4, а перше отелення - у віці 27,6 місяця, тварин молочно-м'ясного типу відповідно у віці 18,0 та 27,1 і тварин м'ясо-молочного типу - 17,5 та 26,7 місяця.

Табличя 4

Жива маса корів різних виробничих типів у період їх вирощування

\begin{tabular}{|c|c|c|c|c|c|c|}
\hline \multirow{2}{*}{ Вік тварин, місяці } & \multicolumn{6}{|c|}{ Виробничий тип } \\
\cline { 2 - 7 } & \multicolumn{2}{|c|}{ молочний $(\mathrm{n}=45)$} & \multicolumn{2}{c|}{ молочно-м'ясний $(\mathrm{n}=94)$} & \multicolumn{2}{c|}{ м'ясо-молочний $(\mathrm{n}=22)$} \\
\cline { 2 - 7 } & $\mathrm{M} \pm \mathrm{m}$, кг & $\mathrm{Cv}, \%$ & $\mathrm{M} \pm \mathrm{m}$, кг & $\mathrm{Cv}, \%$ & $\mathrm{M} \pm \mathrm{m}, \mathrm{\kappa} \Gamma$ & $\mathrm{Cv}, \%$ \\
\hline Новонароджені & $37,9 \pm 0,30$ & 5,25 & $38,2 \pm 0,16$ & 4,06 & $39,6 \pm 0,21 * * *$ & 2,44 \\
\hline 6 міс. & $185,0 \pm 1,22$ & 4,32 & $189,7 \pm 0,74 * *$ & 3,67 & $203,0 \pm 1,55^{* * *}$ & 3,51 \\
\hline 12 міс. & $313,2 \pm 1,87$ & 4,00 & $323,1 \pm 1,17 * * *$ & 3,45 & $343,2 \pm 2,88^{* * *}$ & 3,84 \\
\hline 18 міс. & $418,2 \pm 2,27$ & 3,64 & $432,1 \pm 1,37 * * *$ & 3,01 & $456,5 \pm 3,60 * * *$ & 3,61 \\
\hline При першому осіменінні & $424,1 \pm 3,25$ & 5,01 & $432,1 \pm 1,37 * *$ & 4,27 & $447,3 \pm 3,41^{* * *}$ & 5,24 \\
\hline При першому отеленні & $524,1 \pm 2,43$ & 2,29 & $530,3 \pm 1,67 *$ & 2,66 & $542,9 \pm 4,03 * * *$ & 3,69 \\
\hline
\end{tabular}

Примітка: У цій та всіх наступних таблицях достовірність різниці показників вказана при порівнянні до тварин молочного типу.

Найменша кратність збільшення живої маси у всі досліджувані вікові періоди відмічена у телиць молочного виробничого типу (табл. 5). За цим показником вони поступалися ровесниць молочно-м'ясного і м'ясо-молочного виробничих типів до 6-місячного віку на 0,1 $(\mathrm{P}<0,05)$ і 0,2 ( $<<0,001)$, до 12-місячного - на 0,2 ( $<<0,05)$ і 0,4 $(\mathrm{P}<0,001)$ та до 18-місячного віку - на 0,2 і 0,4 рази $(\mathrm{P}<0,001)$ відповідно. Коефіцієнти мінливості кратності збільшення живої маси найвищими були у телиць молочного типу (5,07-5,48 \%), а найнижчі їх значення відмічено у особин м'ясо-молочного типу $(2,37-3,21 \%)$.

Таблиия 5

Кратність збільшення живої маси корів різних виробничих типів у період їх вирощування

\begin{tabular}{|c|c|c|c|c|c|c|}
\hline \multirow{2}{*}{ Вік тварин, місяці } & \multicolumn{5}{|c|}{ Виробничий тип } \\
\cline { 2 - 7 } & \multicolumn{2}{|c|}{ молочний $(\mathrm{n}=45)$} & \multicolumn{2}{|c|}{ молочно-м'ясний $(\mathrm{n}=94)$} & \multicolumn{2}{c|}{ м'ясо-молочний $(\mathrm{n}=22)$} \\
\cline { 2 - 7 } & $\mathrm{M} \pm \mathrm{m}$, рази & $\mathrm{Cv}, \%$ & $\mathrm{M} \pm \mathrm{m}$, рази & $\mathrm{Cv}, \%$ & $\mathrm{M} \pm \mathrm{m}$, рази & $\mathrm{Cv}, \%$ \\
\hline 6 & $4,9 \pm 0,04$ & 5,48 & $5,0 \pm 0,02 *$ & 4,12 & $5,1 \pm 0,03 * * *$ & 2,37 \\
\hline 12 & $8,3 \pm 0,07$ & 5,30 & $8,5 \pm 0,04 *$ & 4,45 & $8,7 \pm 0,06 * * *$ & 3,21 \\
\hline 18 & $11,1 \pm 0,09$ & 5,07 & $11,3 \pm 0,05$ & 4,45 & $11,5 \pm 0,07 * * *$ & 2,92 \\
\hline
\end{tabular}

Телиці всіх виробничих типів характеризувалися вищою інтенсивністю росту у період від народження до 6-місячного віку (табл. 6). 
Середньодобовий приріст корів різних виробничих типів у період їх вирощування

\begin{tabular}{|c|c|c|c|c|c|c|}
\hline \multirow{3}{*}{$\begin{array}{c}\text { Віковий період, } \\
\text { місяці }\end{array}$} & \multicolumn{6}{|c|}{ Виробничий тип } \\
\hline & \multicolumn{2}{|c|}{ молочний $(\mathrm{n}=45)$} & \multicolumn{2}{|c|}{ молочно-м'ясний $(\mathrm{n}=94)$} & \multicolumn{2}{|c|}{ м'ясо-молочний $(\mathrm{n}=22)$} \\
\hline & $\mathrm{M} \pm \mathrm{m}, \Gamma$ & $\mathrm{Cv}, \%$ & $\mathrm{M} \pm \mathrm{m}, \Gamma$ & $\mathrm{Cv}, \%$ & $\mathrm{M} \pm \mathrm{m}, \Gamma$ & $\mathrm{Cv}, \%$ \\
\hline $0-6$ & $806,5 \pm 6,22$ & 5,17 & $830,6 \pm 3,73 * *$ & 4,36 & $895,9 \pm 7,70 * * *$ & 3,94 \\
\hline $6-12$ & $702,9 \pm 5,66$ & 5,40 & $731,1 \pm 3,95 * * *$ & 5,24 & $768,5 \pm 9,97 * * *$ & 5,95 \\
\hline $12-18$ & $575,3 \pm 7,12$ & 8,30 & $597,8 \pm 4,25 * *$ & 6,88 & $624,5 \pm 9,92 * *$ & 7,31 \\
\hline $0-18$ & $713,2 \pm 3,94$ & 3,70 & $728,9 \pm 2,45 * *$ & 3,26 & $762,0 \pm 6,35 * * *$ & 3,82 \\
\hline
\end{tabular}

Найнижчі середньодобові прирости у всі досліджувані вікові періоди спостерігалися у тварин молочного типу. Зокрема, у період від народження до 6-місячного віку вони поступалися за вищенаведеним показником ровесницям молочно-м'ясного типу на 24,1 $(\mathrm{P}<0,01)$, а м'ясо-молочного - на 89,4 г $(\mathrm{P}<0,001)$, у період від 6- до 12-місячного віку відповідно на 28,2 ( $\mathrm{P}<0,001)$ та 65,6 ( $<0,001)$, у період від 12- до 18-місячного віку - на 22,5 $(\mathrm{P}<0,01)$ та 49,2 (P<0,01) і за весь період вирощування (від народження до 18-місячного віку) на 15,7 ( $<<0,01)$ та 48,8 г $(\mathrm{P}<0,001)$.

Щодо відносної швидкості та напруги росту живої маси у період від народження до 6місячного віку, то достовірно нижчими ці показники були у телиць молочного типу (табл. 7). У решту вікові періоди зазначені показники, хоч і недостовірно, однак вищими були у тварин молочно-м'ясного типу, а найнижчими - у особин м'ясо-молочного типу.

Таблиця 7

Відносна швидкість та напруга росту живої маси корів різних виробничих типів у період їх вирощування, \%

\begin{tabular}{|c|c|c|c|c|c|c|}
\hline \multirow{3}{*}{$\begin{array}{l}\text { Віковий період, } \\
\text { місяці }\end{array}$} & \multicolumn{6}{|c|}{ Виробничий тип } \\
\hline & \multicolumn{2}{|c|}{ молочний (n=45) } & \multicolumn{2}{|c|}{ молочно-м'ясний $(\mathrm{n}=94)$} & \multicolumn{2}{|c|}{ м'ясо-молочний $(\mathrm{n}=22)$} \\
\hline & $\mathrm{M} \pm \mathrm{m}$ & $\mathrm{Cv}$ & $\mathrm{M} \pm \mathrm{m}$ & $\mathrm{CV}$ & $\mathrm{M} \pm \mathrm{m}$ & $\mathrm{Cv}$ \\
\hline \multicolumn{7}{|c|}{ Відносна швидкість росту живої маси } \\
\hline $0-6$ & $131,9 \pm 0,45$ & 2,31 & $132,9 \pm 0,24$ & 1,73 & $134,7 \pm 0,28 * * *$ & 0,95 \\
\hline $6-12$ & $51,5 \pm 0,32$ & 4,15 & $52,0 \pm 0,22$ & 6,49 & $51,3 \pm 0,43$ & 3,88 \\
\hline $12-18$ & $28,7 \pm 0,34$ & 8,00 & $28,9 \pm 0,20$ & 6,76 & $28,4 \pm 0,41$ & 6,64 \\
\hline \multicolumn{7}{|c|}{ Напруга росту живої маси } \\
\hline $0-6$ & $388,9 \pm 3,99$ & 6,89 & $396,6 \pm 2,11$ & 5,17 & $412,1 \pm 2,66^{* * *}$ & 2,95 \\
\hline $6-12$ & $69,4 \pm 0,58$ & 5,60 & $70,3 \pm 0,41$ & 5,61 & $69,1 \pm 0,80$ & 5,28 \\
\hline $12-18$ & $33,6 \pm 0,47$ & 9,49 & $33,8 \pm 0,28$ & 7,88 & $33,1 \pm 0,56$ & 7,71 \\
\hline
\end{tabular}

Однофакторним дисперсійним аналізом було встановлено, що сила впливу належності тварин до того чи іншого виробничого типу на формування їх живої маси у період вирощування становила 8,8-36,9 \% від загальної фенотипової мінливості (табл. 8).

Табличя 8 Сила впливу належності тварин до виробничого типу на формування їх живої маси у період вирощування

\begin{tabular}{|c|c|c|c|}
\hline Жива маса у віці & $\begin{array}{c}\text { Сила впливу, } \\
\eta_{\mathrm{x}}{ }^{2} \pm \mathrm{m}_{\eta}, \%\end{array}$ & $\mathrm{~F}$ & $\mathrm{P}$ \\
\hline Новонароджені & $8,8 \pm 1,25 * * *$ & 7,6 & $<001$ \\
\hline 6 місяців & $33,4 \pm 1,12 * * *$ & 39,6 & $<000$ \\
\hline 12 місяців & $35,5 \pm 1,11 * * *$ & 43,6 & $<000$ \\
\hline 18 місяців & $36,9 \pm 1,09 * * *$ & 46,3 & $<000$ \\
\hline при першому осіменінні & $33,7 \pm 1,12 * * *$ & 40,2 & $<000$ \\
\hline при першому отеленні & $13,4 \pm 1,24 * * *$ & 12,2 & $<000$ \\
\hline
\end{tabular}

Примітка: число ступенів свободи організованого фактора - 2, а неорганізованого - 158 .

Причому найменше даний фактор впливав на живу масу новонародженого молодняку $(8,8 \%)$ та на живу масу тварин після першого отелення $(13,4 \%)$. Варто зазначити, що 
показники сили впливу у всі вікові періоди були високодостовірними як за критерієм Ст'юдента, так і за критерієм Фішера.

\section{В И С Н О В К И}

1. Корови симентальської породи у період вирощування відзначалися добрими показниками живої маси. У всі вікові періоди вони за цим показником переважали стандарт породи: у 6-місячному віці - на 20,2, 12-місячному - на 39,1 та у 18-місячному - на 51,6 кг.

2. Вік першого осіменіння телиць симентальської породи у підконтрольному стаді становив в середньому 18,0, а вік першого отелення - 27,2 місяця при живій масі 433,7 та 529,1 кг, відповідно.

3. Жива маса телиць залежала від їх виробничого типу. У всі досліджувані періоди росту найнижчими показниками живої маси, кратності збільшення живої маси та середньодобових приростів характеризувалися тварини молочного типу, а найвищими - м'ясо-молочного. Особини м'ясо-молочного типу відзначалися кращою скороспілістю. Вік першого осіменіння у них становив 17,5 місяця, тоді як особин молочно-м'ясного типу - 18,4, а м'ясо-молочного типу - у 18,0 місяців.

4. Сила впливу належності корів до виробничого типу на формування їх живої маси у період вирощування становила 8,8-36,9 \% від загальної фенотипової мінливості, причому найменше даний фактор впливав на живу масу новонародженого молодняку $(8,8$ \%) та на живу масу тварин після першого отелення (13,4 \%).

Перспективи досліджень. У подальшому буде вивчено екстер'єрні особливості корів різних виробничих типів симентальської породи.

\section{DYNAMICS OF EARLY GROWTH OF HEIFERS OF SIMMENTAL BREEDS OF DIFFERENT PRODUCTION TYPES}

\section{T. V. Orikhivskyi ${ }^{1}$, V. V. Fedorovych ${ }^{2,3}$, N. P.Mazur ${ }^{4}$, Alice Pirlog $^{5}$}

${ }^{1}$ Lviv National University of Veterinary Medicine and Biotechnologies named after S.Z.Gzhytskyy, 50, Pekarska Street, Lviv, 79000, Ukraine,

${ }^{2}$ Institute of Animal Breeding and Genetics named after M.V. Zubets NAAS, Kyiv district, Chubynske village, Pogrebnyaka Street 1, 08231, Ukraine,

${ }^{3}$ Institute of agricultural industry of Carpathian region NAAS, Lviv district, Obroshyne village, Grushevskyy Street 5, 81115, Ukraine,

${ }^{4}$ Institute of Animal Biology of NAAS, 38, V. Stus street, Lviv, 79034, Ukraine,

${ }^{5}$ State Agrarian University of Moldova. 42, Mircești Street, Chişinău, MD 2049, Moldova

\section{S U M M A R Y}

One of the important factors in the economic efficiency of the dairy industry is growing healing heifers. The purpose of the work was to study the dynamics of live weight of cows of Simmental breed of different production types during their growing season. Research was conducted at farm enterprise "Litynske" of Drohobych district of Lviv oblast. 161 animals were involved to research which were studied by the live weight, multiplicity of increase in live weight, average daily increments, relative intensity and growth stress of living mass in different age periods, as well as the age of their first insemination and first calving. 
It was established that the Simmental breed cows during the growing period in the young the ages were marked by good indicators of live weight. In all ages they were the prevailing standard breed by this indicator: at 6 months of age - by 20.2, in 12-month - by 39.1 and in the 18 -month by $51.6 \mathrm{~kg}$. Age of first insemination of heifers was at average of 18.0 in a controlled herd, and the age of the first calving was 27.2 months with a live weight of 433.7 and $529.1 \mathrm{~kg}$ respectively. The live mass of healing heifers depended on their production type. During the all studied periods of growth dairy animals were characterized by the lowest indicators of live weight, multiplicity of increase live weight and average daily increments, as well the highest - meat and dairy. Dairy heifers had significantly lower than these figures, in particular relative velocity and tension of live weight growth in from birth to 6 months of age. In the rest of the ages, the indicated indicators, though unreliable, meat and dairy type had the highest, and dairy type had the lowest indicators.

Individuals of meat and dairy type were the best in earliness. Age of the first insemination was 17.5 months, while the individuals of dairy and meat type - 18.4, and meat and dairy type - in 18,0 months. Strength of the influence of cows belonging to the production type on the formation of their live weight during the period of cultivation was $8.8-36.9 \%$ of the total phenotypic variability, with the least factor influencing the live weight newborn young $(8.8 \%)$ and live weight of animals after the first calving (13.4\%).

Keywords: SIMMENTAL BREED, PRODUCTION TYPE, HEIFERS, LIVING WEIGHT, MIDDLE EARNINGS, FIRST INSEMINATION AGE, FIRST CALVING AGE, INFLUENCE EFFECT.

\title{
ДИНАМИКА ВЕСОВОГО РОСТА ТЕЛОК СИММЕНТАЛЬСКОЙ ПОРОДЫ РАЗЛИЧНЫХ ПРОИЗВОДСТВЕННЫХ ТИПОВ
}

\author{
Т. В. Орихивский , В. В. Федорович ${ }^{2,3}$, Н. П. Мазур ${ }^{4}$, Алиса Пырлог ${ }^{5}$
}

${ }^{1}$ Львовский национальный университет ветеринарной медицины и биотехнологий имени С.3. Гжицкого, ул. Пекарская, 50, г. Львов, 79000, Украина

${ }^{2}$ Институт разведения и генетики животных имени М. В. Зубца НААН, ул. Погребняка, 1, с. Чубинское Бориспольского района Киевской области, 08321, Украина

${ }^{3}$ Институт сельского хозяйства Карпатского региона НААН, ул. Грушевского, 5, с. Оброшино, Пустомытовского р-на Львовской области, 81115, Украина

$$
\begin{gathered}
{ }^{4} \text { Институт биологии животных НАAН, } \\
\text { ул. В. Стуса, 38, г. Львов, 79034, Украина } \\
{ }^{5} \text { Государственный аграрный университет Молдовы. } \\
\text { ул Мирчешть, 42, г. Кишинев, MD } 2049 \text { Молдова, }
\end{gathered}
$$

\section{А Н Н О Т А ЦИ Я}

Приведены данные весового роста коров симментальской породы в период выращивания в молодом возрасте в зависимости от их производственного типа. Установлено, что животные с живой массой в 6-месячном возрасте преобладали стандарт породы на 20,2, в 12-месячном - на 39,1 и в 18-месячном - на 51,6 кг. Возраст первого осеменения телок в подконтрольном стаде составлял 18,0, а возраст первого отела - 27,2 месяца при живой массе 433,7 и 529,1 кг соответственно. Во все исследуемые периоды роста низкими показателями живой массы, кратности увеличения живой массы и среднесуточных приростов характеризовались животные молочного типа, а самыми высокими - мясо-молочного. Телки мясо-молочного типа отличались лучшей скороспелостью. Возраст первого осеменения у них составлял 17,5 месяца, тогда как у особей молочно-мясного типа - 18,4, а мясо-молочного типа 
- 18,0 месяцев. Сила влияния принадлежности животных к производственному типу на формирование их живой массы, в зависимости от периода выращивания, составляла 8,8$36,9 \%$ от общей фенотипической изменчивости, причем меньше данный фактор влиял на живую массу новорожденного молодняка $(8,8$ \%) и на живую массу животных после первого отела $(13,4 \%)$.

КлючевЫе слова: СИММЕНТАЛЬСКАЯ ПОРОДА, ПРОИЗВОДСТВЕННЫЙ ТИП, ТЕЛКИ, ЖИВАЯ МАССА, СРЕДНЕСУТОЧНЫЕ ПРИРОСТЫ, ВОЗРАСТ ПЕРВОГО ОСЕМЕНЕНИЯ, ВОЗРАСТ ПЕРВОГО ОТЕЛА, СИЛА ВЛИЯНИЯ.

\section{Л I T E P A T У P A}

1. Айсанов 3. Определение производственных типов крупного рогатого скота молочных пород // Молочное и мясное скотоводство. - 1997. - №1. - С. 29-30.

2. Базишин М. Розвиток теличок різного походження / М. Базишин // Тваринництво України. - 2008. - №3. - С. 26-28.

3. Бащенко М. I. Симентали Черкащини: монографія / М. І. Бащенко, А. М. Дубін. Київ, 2009. - 236 с.

4. Выращивание ремонтных телок при различном уровне кормления / А. С. Козлов, С. В. Мошкина, А. А. Костиков, Н. В. Абрамкова // Зоотехния - 2002. - №2 - С. 20-22.

5. Гавриленко M. Вимоги до росту і розвитку племінних телиць / М. Гавриленко // Пропозиція. - 2001. - №8. - С. 80-81.

6. Коваль Т. П. Інтенсивність формування живої маси телиць та іï зв'язок 3 продуктивністю / Т. П. Коваль // Розведення і генетика тварин. Київ, 2007. - Вип. 41. - С. 93103.

7. Лакин Г. Ф. Биометрия : учеб. пособ. для биол. спец. вузов. Москва : Высшая школа, 1990. $352 \mathrm{c}$.

8. Титаренко I. B. Вплив інтенсивності вирощування телиць на їх відтворну здатність та молочну продуктивність / I. В. Титаренко, М. В. Буштрук, I. С. Старостенко // Науковотехнічний бюлетень НДЦ біобезпеки та екологічного контролю ресурсів АПК. - Дніпро, 2016. - T.4, №1. - С. 260-266.

9. Федорович $B$. В. Молочна продуктивність корів симентальської породи залежно від ïx живої маси у період вирощування / В. В. Федорович // Науковий вісник Львівського національного університету ветеринарної медицини та біотехнологій імені С. 3. Гжицкого. Львів, 2017. - Т. 19, № 79. - С. 93-99. doi:10.15421/nvlvet7919

10. Характеристика корів симентальської породи за господарськи корисними ознаками в умовах Львівщини / В. В. Федорович, Т. В. Оріхівський, Н. П. Бабік та ін. // Науковий вісник Львівського національного університету ветеринарної медицини та біотехнологій імені С. 3. Гжицкого. - Львів, 2016. - Т. 18, № 2(67). - С. 255-260. doi:10.15421/nvlvet6756

\section{References}

1. Aysanov Z. Opredelenie proizvodstvennyih tipov krupnogo rogatogo skota molochnyih porod. Molochnoe i myasnoe skotovodstvo, 1997, no 1, pp. 29-30. (in Russian).

2. Bazyshyn, M. Rozvytok telychok riznoho pokhodzhennia. Tvarynnytstvo Ukrainy. 2008, no 3, pp. 26-28 (in Ukrainian).

3. Bashhenko, M.I., Dubin, A.M. Symentaly Cherkashhyny: monografija. Kyi'v. 2009, 236 p. (in Ukrainian).

4. Kozlov A. S., Moshkina S. V., Kostikov A. A., Abramkova N. V. Vyiraschivanie remontnyih telok pri razlichnom urovne kormleniya. Zootehniya, 2002. no 2, pp. 20-22 (in Russian). 
5. Havrylenko M. Vymohy do rostu i rozvytku pleminnykh telyts. Propozytsiia, 2001, no 8, pp. 80-81 (in Ukrainian).

6. Koval, T.P. Intensyvnist formuvannia zhyvoi masy telyts ta yii zviazok z produktyvnistiu. Rozvedennia i henetyka tvaryn. 2007, vol. 41, pp. 93-103 (in Ukrainian).

7. Lakin G. F. Biometriya : ucheb. posob. dlya biol. spets. vuzov. Moskva : Vyisshaya shkola, 1990. $352 \mathrm{p}$.

8. Tytarenko I. V., Bushtruk M. V., Starostenko I. S. Vplyv intensyvnosti vyroshchuvannia telyts na yikh vidtvornu zdatnist ta molochnu produktyvnist. Naukovo-tekhnichnyi biuleten NDTS biobezpeky ta ekolohichnoho kontroliu resursiv APK, 2016. vol. 4, no 1, pp. 260-266 (in Ukrainian).

9. Fedorovych, V.V. Dairy productivity of Simmental breed cows depending on their live weight during growing period. Scientific Messenger LNUVMB, 2017, vol. 19(79), pp.93-99. DOI:10.15421/nvlvet7919 (in Ukrainian).

10. Fedorovych, V.V., Orihivskyy, T.V., Babik, N.P., Fedorovych, E.I., Oseredchuk, R.S. The characteristics of simmentals by their economically useful traits in the conditions of Lviv region. Scientific Messenger LNUVMBT named after S.Z. Gzhytskyj, 2016, vol. 18, no 2(67), pp. 255-260. DOI:10.15421/nvlvet6756 (in Ukrainian).

Рецензент - М. І. Кузів, д. с.-г. н., с. н. с., Інститут біології тварин НААН. 